УДК 633(477.61)

(C) 2012

Зубов О. Р., доктор сільськогосподарських наук, професор,

Зубова Л. Г., доктор технічних наук, професор, Славгородська Ю. В., аспірант *

Східноукраїнський національний університет імені Володимира Даля, м. Луганськ

\title{
ОЦІНКА ВПЛИВУ МЕТЕОРОЛОГІЧНИХ ФАКТОРІВ НА ВРОЖАЙНІСТЬ ОЗИМИХ КУЛЬТУР В УМОВАХ ПІВНІЧНОЇ ЧАСТИНИ ЛУГАНСЬКОЇ ОБЛАСТІ
}

\section{Рецензент - доктор сільськогосподарських наук, професор М. І. Конопля}

\begin{abstract}
На прикладі типового аграрного підприємства півночі Луганської області здійснено комплексний аналіз кліматичних факторів і продуктивності аграрних ландшафтів. У результаті досліджень визначено математико-статистичні моделі кореляиійної залежності врожайності озимих культур від метеорологічних факторів за 36-річний період.

Установлено, щчо для пшениці озимої найбільи впливовими метеорологічними факторами є кіль-

кість опадів червня, вересня і травня; для жита озимого - кількість опадів червня, вересня і квітня.
\end{abstract}

Ключові слова: пшениия озима, жито озиме, врожайність, метеорологічні фактори.

Постановка проблеми. Формування врожаю сільськогосподарських культур, у тому числі й озимих, пов'язане з комплексом абіотичних факторів, із-поміж яких важливе місце займають природно-кліматичні умови. Не дивлячись на значну кількість досліджень, які мають на меті встановити залежність між біологічною продуктивністю і метеорологічними факторами та проводяться 3 різними сільськогосподарськими культурами, оптимальні показники метеорологічних факторів для схожих грунтовокліматичних умов коливаються у широких межах. Ця проблема залишається актуальною і в даний час, оскільки потреба в періодичному уточненні оптимумів кількості вологи й тепла буде існувати завжди у зв'язку зі зміною метеорологічних умов.

Аналіз основних досліджень i публікацій, у яких започатковано розв'язання проблеми. Питання залежності урожайності культур від кліматичних факторів розглядали В. Дмитренко [1], В. Калініченко [4], А. Полевой [6], Ю. Тараріко [10]. В умовах сходу країни проблему досліджували О. Долгіх, О. Мостовий, Л. Попитченко, I. Соколов, Г. Стародворов, П. Шеліхов тощо [79]. Зокрема, вченими відзначається, що в Україні в останні роки проводяться роботи по оцінці реакції зернових культур на зміну клімату та умов вирощування сільськогосподарських культур [7]. Для більш якісного інформаційного забезпечення сільськогосподасрького виробництва, прогнозування продуктивності окремих культур доцільно проводити дослідження на локальному, регіональному та державному рівнях [10]. Однією з проблем адаптації рослин до місцевих агрокліматичних умов є визначення оптимального рівня тепла та вологи [7].

Мета даної роботи - виявити вплив метеорологічних факторів на врожайність озимих культур в умовах північної частини Луганської області.

Завдання дослідження - встановити кореляційну залежність врожайності озимих культур від метеорологічних факторів.

Об'єкт дослідження - угіддя сільськогосподарського підприємства «Оріон» Марківського району Луганської області - типові за природними умовами ії північної частини.

Методика дослідження. Вплив метеорологічних факторів на врожайність озимих культур визначали за допомогою кореляційно-регресійного аналізу. Досліджували залежність показників урожайності пшениці озимої та жита озимого від таких метеоданих, як середньомісячні показники температури повітря та кількості опадів із квітня до серпня, сума опадів із жовтня до березня, ГТК; кількість опадів і температура вересня, жовтня року посіву. Перший фактор, що визначався при аналізі, $є$ найбільш впливовим, після його вилучення розрахунки повторювалися, виявлялися ще декілька факторів та визначався коефіцієнт множинної кореляції. Дані про врожайність сільськогосподарських культур зібрані за матеріалами іiі обліку в агропідриємстві «Оріон», гідрометеорологічні дані бралися по Біловодській гідрометеорологічній станції (найближчій до господарства) за період із 1971 до 2006 року.

* Керівник-доктор сільськогосподарських наук О. Р. Зубов 
Результати досліджень. За період обліку урожайності 31971 по 2006 рр. урожайність пшениці озимої коливалася від 11 до 41,3 ц/га; жита озимого - від 8,4 до 42,3 ц/га. Середня врожайність пшениці озимої становила 25,7 ц/га, жита озимого - 24,6 ц/га. Високі показники врожайності культур були в 1988, 1990, 1992, 1993, 1995, 2001, 2005 роках. Найгіршими за показниками врожайності виявилися 1972, 1975, 1998, 2006 роки. В 1972 р. (у січні та лютому) випала найменша кількість опадів (1,7 мм та 0,5 мм відповідно) й спостерігалася найнижча температура січня $\left(-15,4{ }^{\circ} \mathrm{C}\right)$. У цьому році показники врожайності озимих найнижчі. Найбільший урожай пшениці озимої отримано в 1989 р., жита озимого - в 2002 році. Найменші показники врожайності пшениці озимої отримано в 1972 р., жита озимого - в 1981 році.

У результаті досліджень встановлено багатофакторні кореляційні залежності врожайності пшениці озимої та жита озимого по СТОВ «Оріон» від метеорологічних факторів за 36-річний період. Визначено, що опади більше впливають на врожайність озимих культур, аніж температуpa. На врожайність пшениці озимої впливають кількості опадів червня, вересня, травня. Врожайність жита озимого залежить від кількості опадів червня та вересня, від температури квітня.

Математична модель залежності врожайності культури від метеорологічних факторів у загальному вигляді має вигляд:

$$
Y=f_{1}\left(X_{1}\right) f_{2}\left(X_{2}\right) f_{3}\left(X_{3}\right) .
$$

Параметри рівнянь окремих функцій математичної моделі по факторах, які впливають на врожайність пшениці озимої, наведені в таблиці 1.

За визначеними математичними моделями кореляційної залежності врожайності культури від метеорологічних показників побудовані графіки функцій. Графік математичної моделі кореляційної залежності від першого визначеного фактора ілюструє розрахункову залежність урожайності культури від опадів червня, двох інших коефіцієнт впливу кількості опадів вересня та травня на врожайність пшениці озимої.

Згідно з графіком (рис. 1а), збільшення кількості опадів червня позначається на підвищенні врожайності пшениці озимої. Максимальна врожайність культури (близько 31 ц/га) прогнозується при показниках опадів червня 114,9 мм.

Аналізуючи врожайність пшениці озимої в СТОВ «Оріон», визначено, що кількість опадів вище середнього значення по кліматичній зоні за роки дослідження (53 мм) забезпечує підвищення врожайності культури. Високий врожай (34,2 ц/га) був у 1978 р., кількість опадів червня у цьому році становила 81,3 мм, у 1987 р. 28,8 ц/га при 80,7 мм опадів, у 1990 р. - 36,5 ц/га при 81,7 мм, у 1993 р. - 35,6 ц/га при 81,7 мм, у 2004 p. - 29,1 ц/га при 99,6 мм. У разі незначної кількості опадів $(9,1$ мм) у 1975 р. отримано невисокий врожай $(17,1$ ц/га), у 1979 р. при 12 мм - 15,5 ц/га.

На рисунках 16 та 1в наведені графіки залежності врожайності пшениці озимої від кількості опадів вересня та травня. 3 графіків видно, що при збільшенні кількості опадів урожайність культури підвищується. Коефіцієнт впливу опадів дорівнює одиниці з кількістю опадів вересня 50 мм, кількості опадів травня 36 мм.

Відомо, що протягом вегетації пшениця озима поглинає вологу нерівномірно. Найбільше вона необхідна рослинам у період трубкування, коли рослина інтенсивно росте і в неї формуються квітки, колоски. Нестача вологи в цей час зумовлює значне зниження врожаю внаслідок меншої кількості зерен у колосі та меншої маси 1000 зерен.

Крім того про високу потребу пшениці озимої у волозі свідчать витрати нею води в процесі формування врожаю. Тривалість періоду від колосіння до повної стиглості зерна становить близько 40 днів [3]. Цей строк у досліджуваній кліматичній зоні припадає на травень - червень, а саме опади в червні - травні визначені нами як фактори, що найбільше впливають на врожайність пшениці озимої.

\section{1. Багатофакторна математико-статистична модель врожсайності пшениці озимої}

\begin{tabular}{|c|c|c|c|}
\hline \multicolumn{2}{|c|}{ Фактор } & Рівняння функції фактора & $\begin{array}{c}\text { Коефіцієнт } \\
\text { множинної } \\
\text { кореляції }\end{array}$ \\
\hline$X_{1}$ & кількість опадів червня & $Y=37,11-71,17 x^{-0,5}$ & 0,47 \\
\hline$X_{2}$ & кількість опадів вересня & $Y=0,718+0,046 x^{0,5}$ & 0,59 \\
\hline$X_{3}$ & кількість опадів травня & $Y=0,88+3,497 * 10^{-4} x^{1,5}$ & 0,68 \\
\hline
\end{tabular}




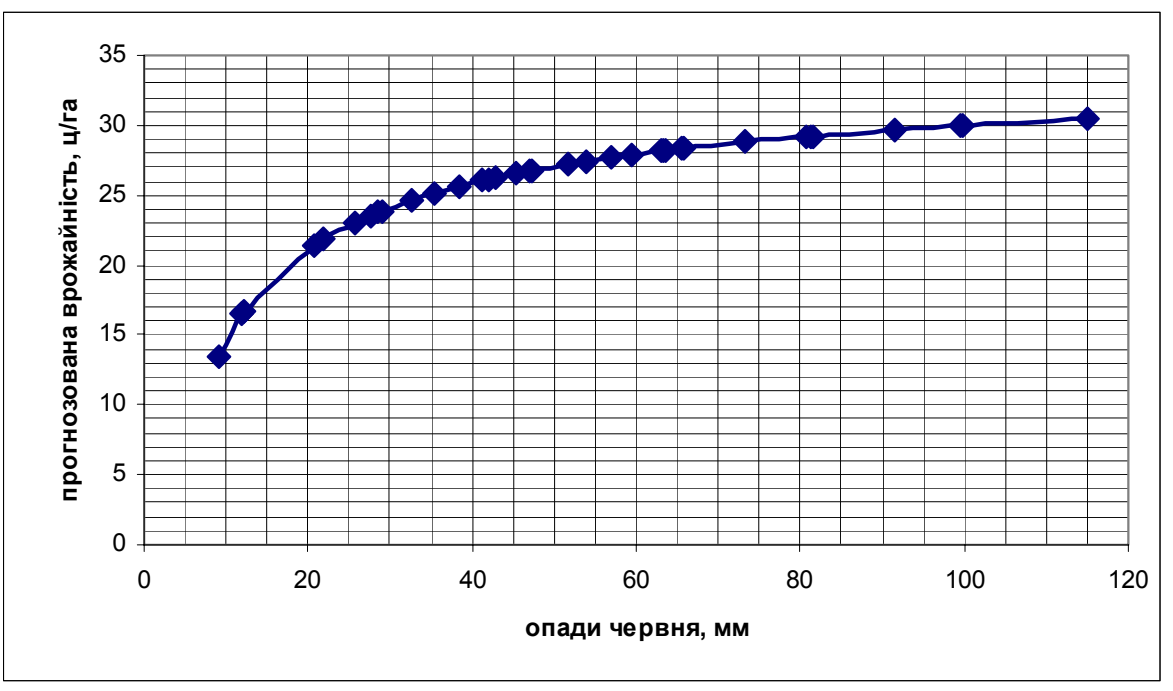

a)

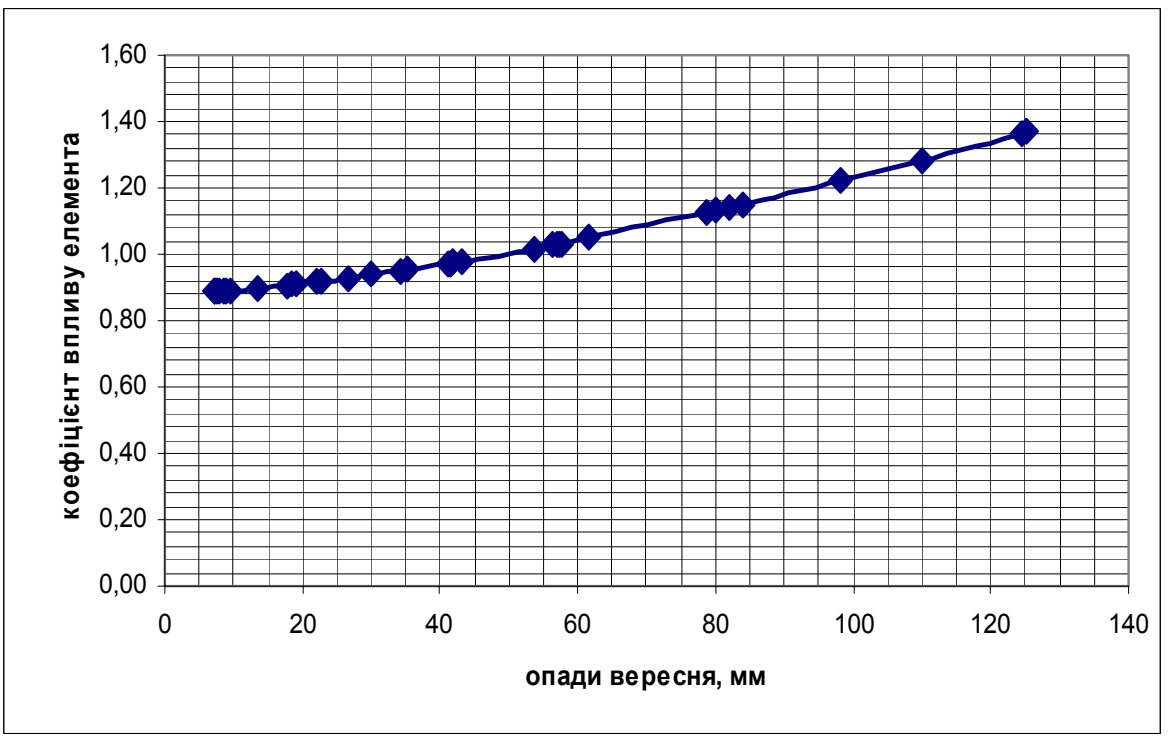

б)

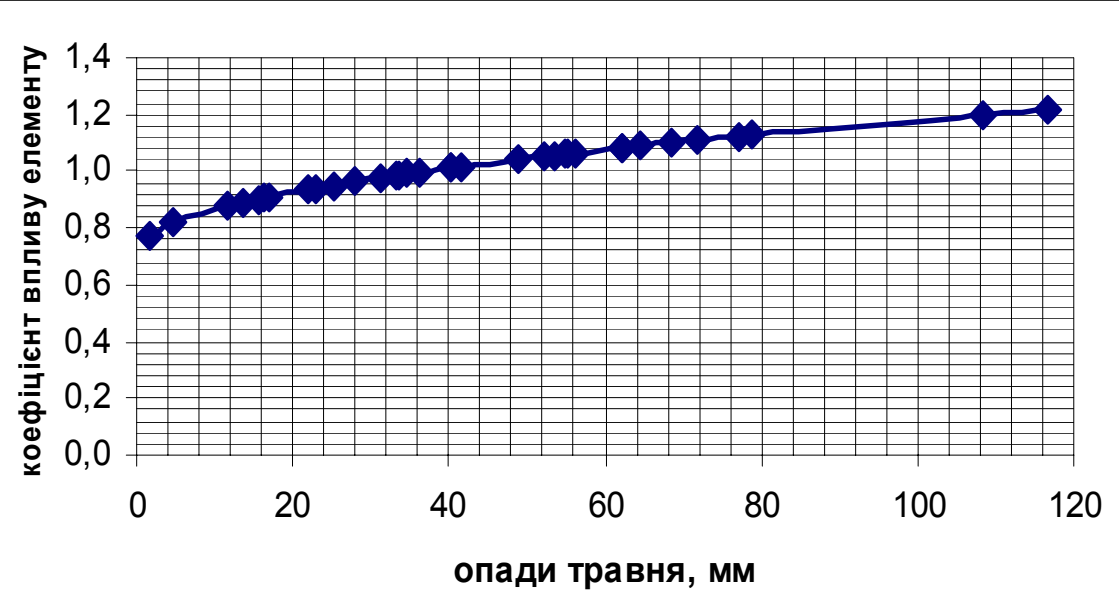

B)

Рис. 1. Розрахункова залежність врожайності пиениці озимої від опадів червня (а), зв'язок врожайності з опадами вересня (б) та травня (в) у коефіцієнтному вигляді

Велике значення має вологість посівного шару на час сівби пшениці. Значні запаси піi у грунті необхідні з самого початку бубнявіння та проро- стання насіння. За достатнього забезпечення рослин водою вони нормально кущаться, формують добре розвинену вторинну кореневу систе- 
му, стають більш зимо- та морозостійкими [2]. Сівба озимих проходить у вересні, тобто опади вересня, визначені нами одним із головних факторів, що впливають на врожайність пшениці озимої, мають виняткове значення в формуванні майбутнього врожаю.

За даними врожайності пшениці озимої було побудовано емпіричну криву вірогідності перевищення (рис. 2), згідно з якою в $97 \%$ усіх випадків урожайність культури перевищуватиме 11 ц/га, в $50 \%-21$ ц/га, у $10 \%-37$ - га.

Досліджуючи залежність врожайності жита озимого від метеорологічних факторів, визначили математико-статистичні моделі, наведені у таблиці 2. Як і для пшениці озимої, факторами, які найбільше впливають на врожайність жита озимого, були опади червня, вересня, а також температура квітня.

Графіки залежностей врожайності жита озимого від визначених метеорологічних факторів наведено на рис. 3.

Зростання врожайності культури спостерігається за збільшення кількості опадів червня (рис. 3a). Максимальна врожайність $(27,1$ ц/га) прогнозується за суми опадів червня 114,9 мм. Жито озиме досить негативно реагує на грунтову й повітряну посухи. Особливо шкодить житу грунтова посуха в період трубкування рослин, коли формуються генеративні органи. Суха погода і спека в період цвітіння негативно впливають на запилення квіток, що викликає череззерницю [3].

Встановлена закономірність залежності врожайності жита озимого від опадів червня простежується й за фактичними даними врожайності досліджуваного господарства. Так, низький врожай отримано за найменшої кількості опадів упродовж 36-річного періоду (9,1 мм) - 13, 2 ц/га в 1975 р.; при незначній кількості опадів (12,2 мм) у 1981 р. врожайність культури була найнижчою - 8,4 ц/га. Висока врожайність пшениці озимої в досліджуваному господарстві за кількості опадів червня 80,7 мм у 1987 р. була 31,7 ц/га, за 91,5 мм у 2003 р. - 26,6 ц/га, за 81,7 мм у 1993 р. $-41,2$ ц/га.

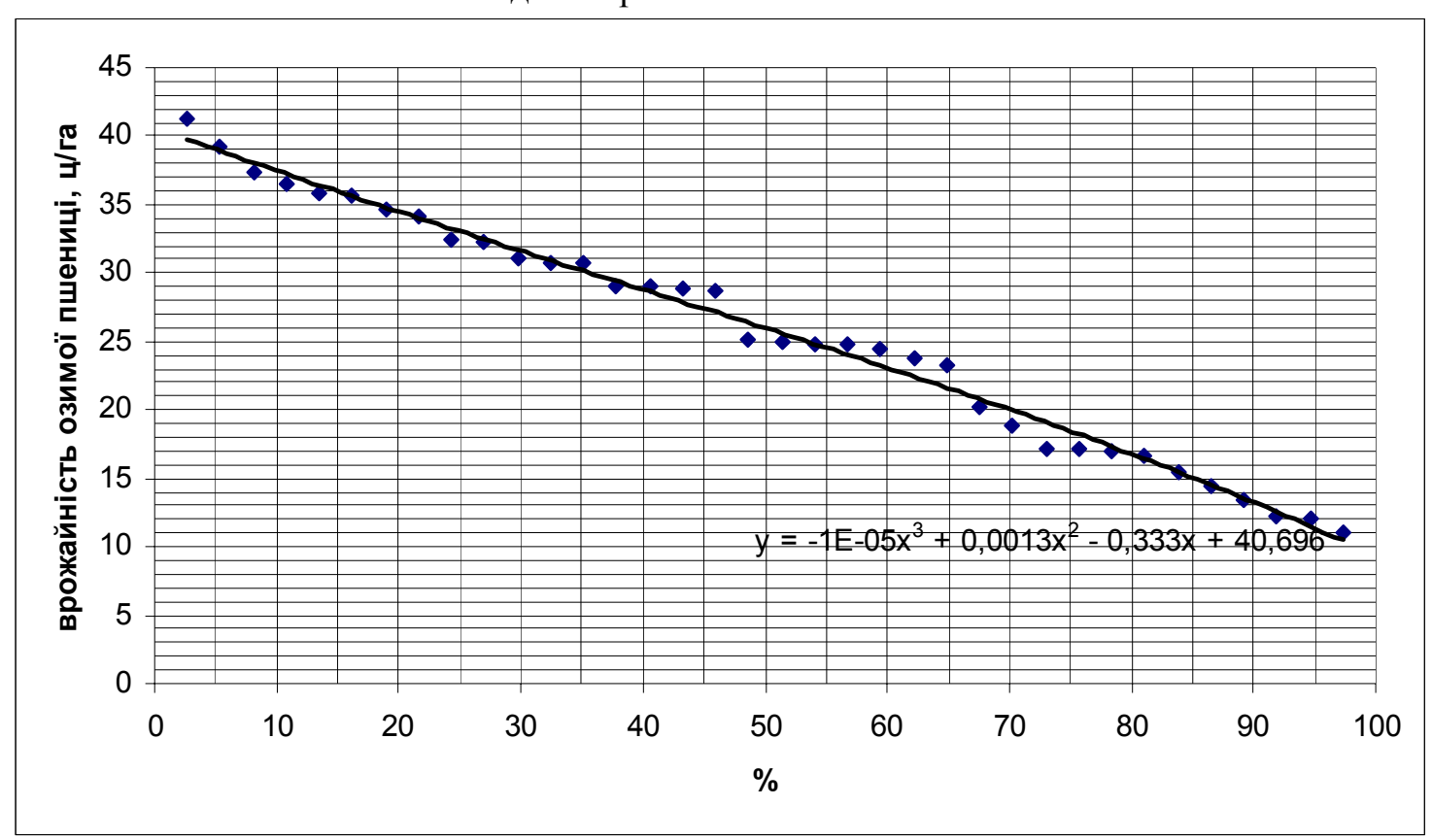

Рис. 2. Емпірична крива вірогідності перевищення врожайності пщениці озимої

2. Багатофакторна математико-статистична модель врожайності жита озимого

\begin{tabular}{|c|c|c|c|}
\hline \multicolumn{2}{|c|}{ Фактор } & Рівняння функції фактора & $\begin{array}{c}\text { Коефіцієнт } \\
\text { множинної } \\
\text { кореляції }\end{array}$ \\
\hline$X_{1}$ & кількість опадів червня & $Y=27,54-500,6 x^{-1,5}$ & 0,44 \\
\hline$X_{2}$ & кількість опадів вересня & $Y=0,858+0,002 x+1,085 * 10^{-5} x^{2}$ & 0,58 \\
\hline$X_{3}$ & температура квітня & $Y=1,504-0,155 x+0,01 x^{2}$ & 0,62 \\
\hline
\end{tabular}


СІЛЬСЬКЕ ГОСПОДАРСТВО. РОСЛИННИЦТВО

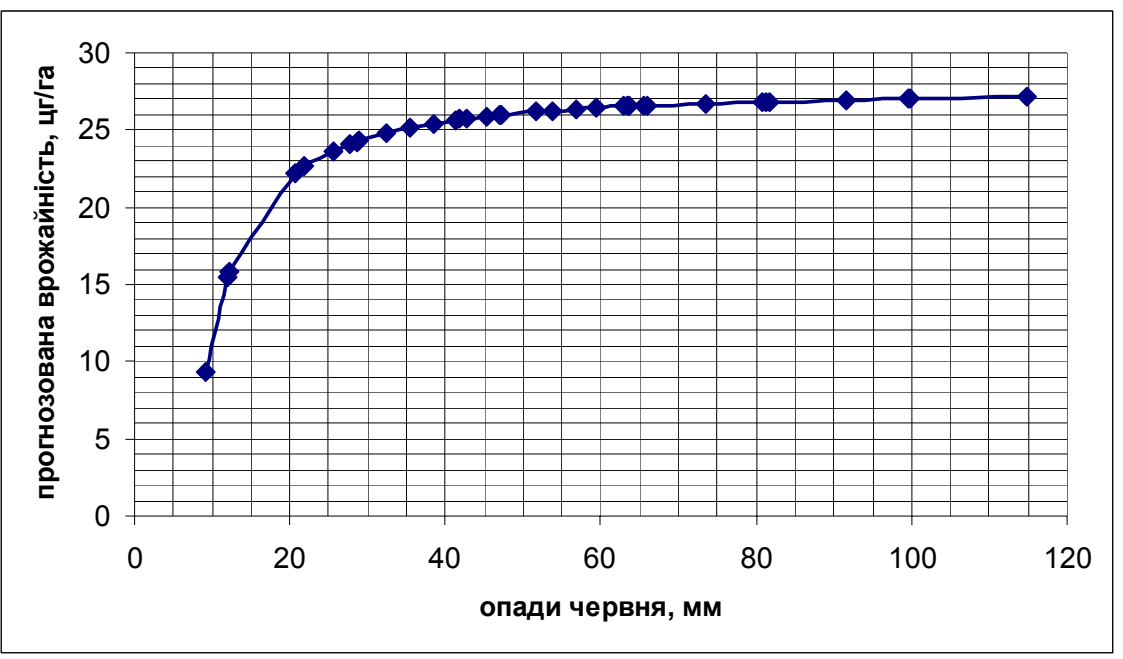

a)

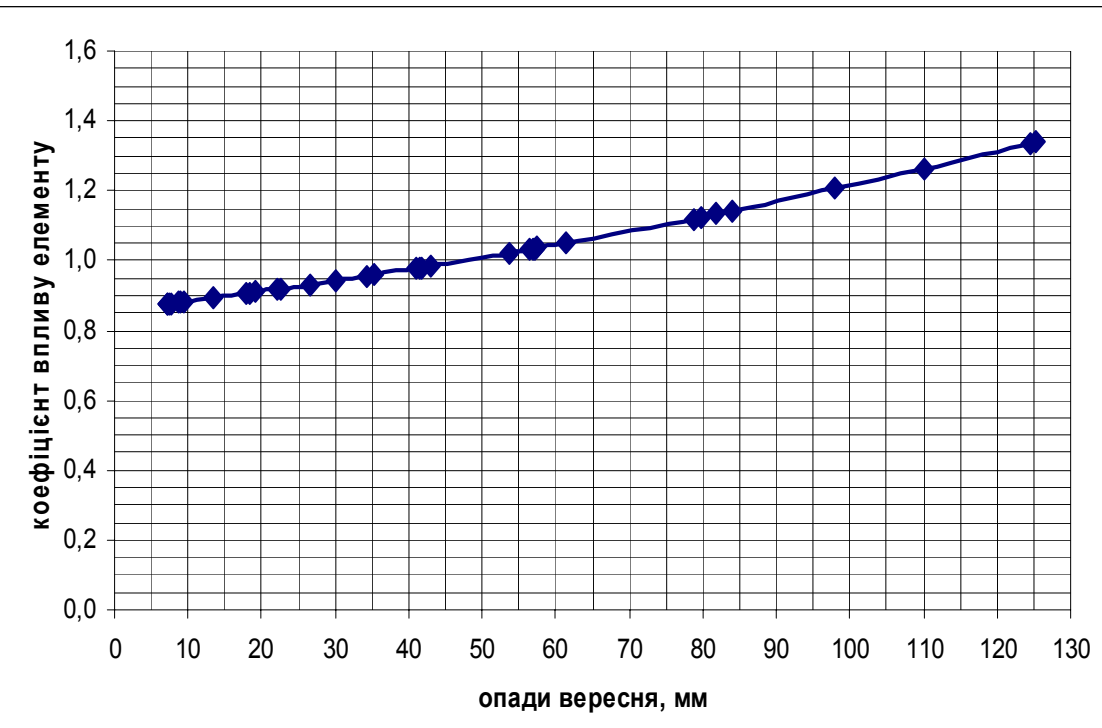

б)

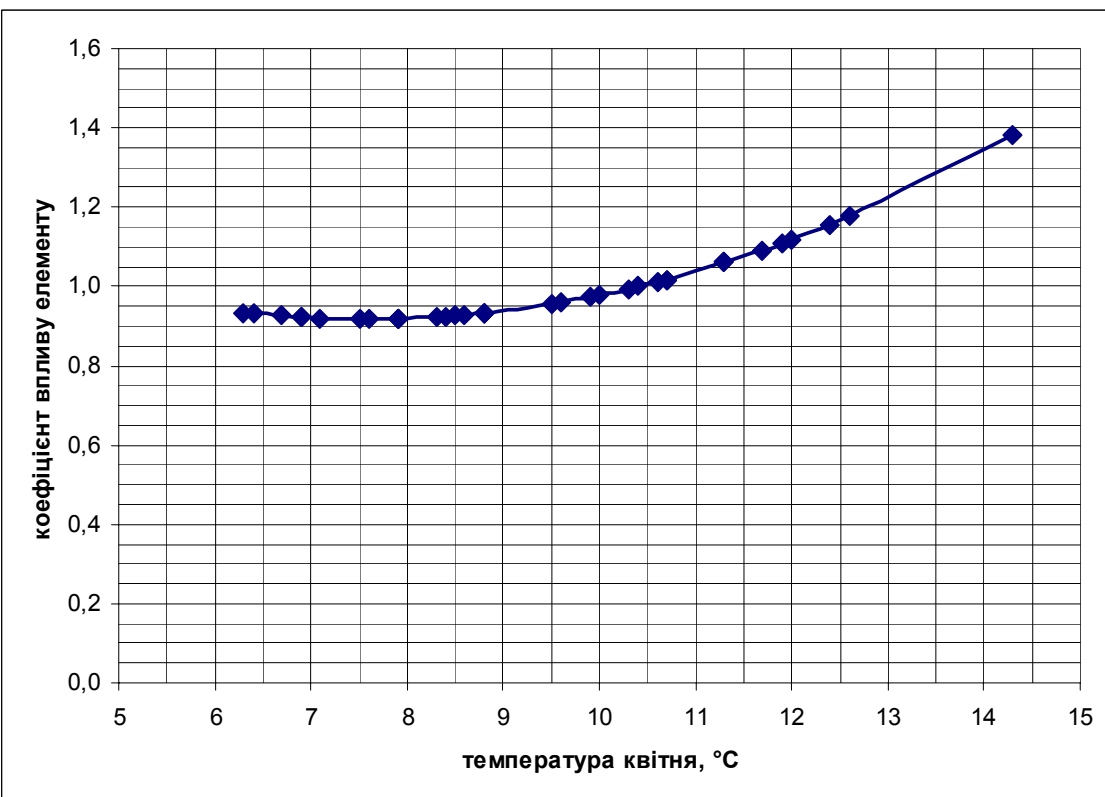

B)

Рис. 3. Розрахункова залежність врожайності жита озимого від опадів червня (a), зв'язок врожайності з опадами вересня (б) та температурою квітня (в) у коефіцієнтному вигляді 


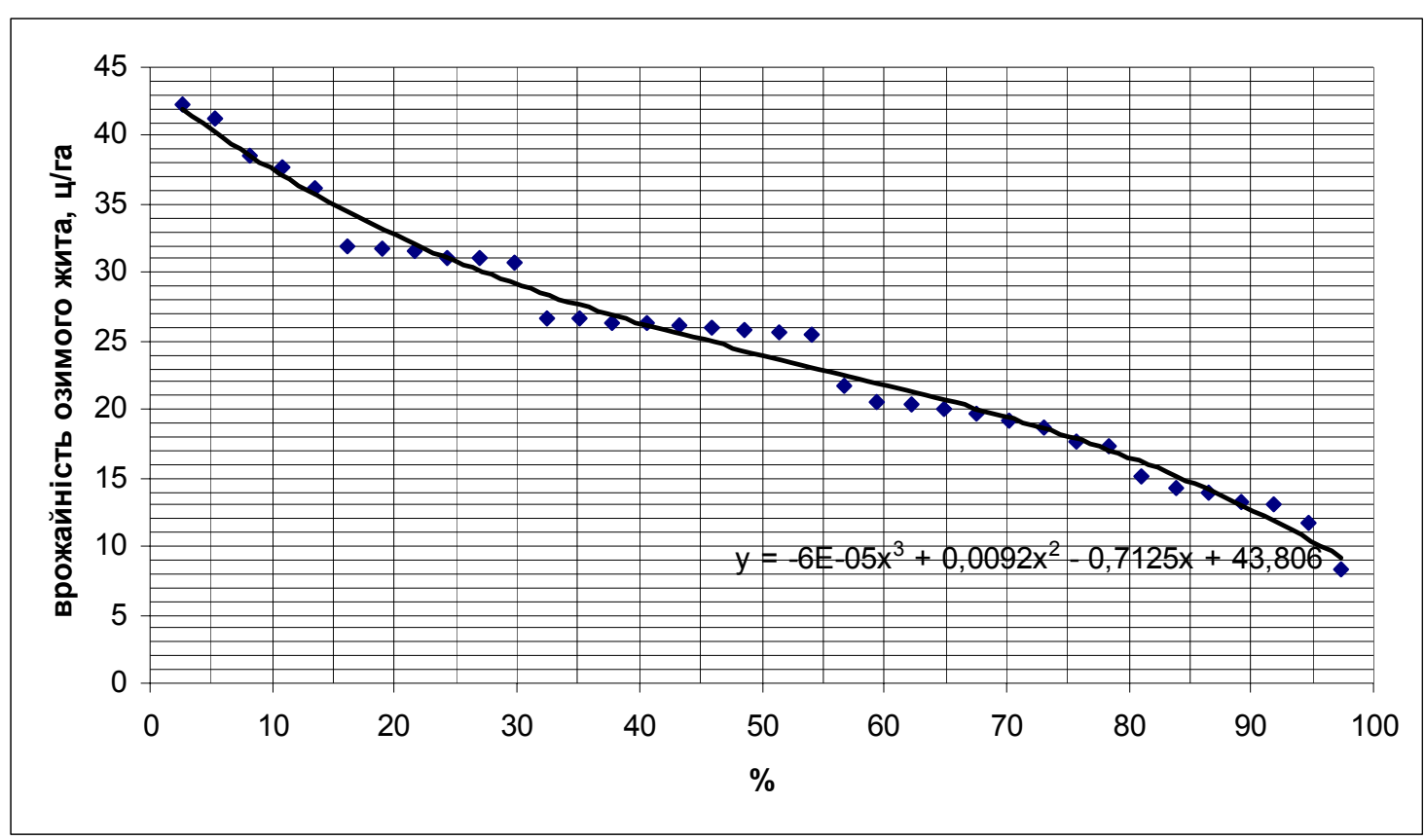

Рис. 4. Емпірична крива вірогідності перевищення врожайності жита озимого

Другим визначеним метеорологічним фактором, що впливає на врожайність жита озимого, $\epsilon$ кількість опадів вересня, третім - температура квітня. 3 графіка на рис. $3 б$ видно, що зі збільшенням кількості опадів вересня врожайність жита озимого підвищується. Коефіцієнт впливу елемента дорівнює одиниці при значенні кількості опадів 47 мм. За недостатньої кількості вологи восени сходи жита озимого бувають досить зрідженими, і рослини погано кущаться [3]. 3 підвищенням температури квітня (рис. 3в) жито активніше відростає, врожайність культури збільшується. Коефіцієнт впливу елемента дорівнює одиниці при значенні температури квітня $10,4{ }^{\circ} \mathrm{C}$.

За даними врожайності жита озимого було побудовано емпіричну криву вірогідності пере-

\section{БІБЛІОГРАФІЯ}

1. Дмитренко В. Л. Адаптації меліоративного землеробства до погоди і клімату / В. Л. Дмитренко // Вісник аграрної науки. - 2003. - № 2. C. $52-56$.

2. Земельні ресурси України / [За ред. В. В. Медведєва, Т. М. Лактіонової]. - К. : Аграрна наука, 1998. $-150 \mathrm{c}$.

3. Зінченко О. I. Рослинництво : [підручник], [Електронний ресурс] / О. І. Зінченко, В. Н. Салатенко, М. А. Білоножко. - К. : Аграрна освіта, 2001. - 591 с. - Режим доступу : http://buklib.net/component/option,com_jbook/Itemi d,99999999/catid,187/

4. Калініченко В. М. Агроекологічне обгрунту- вищення (рис. 4). Врожайність культури перевищуватиме 38 ц/га в $10 \%$ усіх випадків, в половині випадків - 24 ц/га, у 97 \% випадках урожайність становить 8 ц/га.

Підсумовуючи отримані результати залежності врожайності озимих культур від абіотичних кліматичних факторів, можна зробити наступні висновки.

Встановлено, що на врожайність пшениці озимої передусім впливають кількість опадів червня, вересня й травня; на врожайність жита озимого - кількість опадів червня, вересня та температура квітня. Розрахунковий максимум урожайності за найбільшої кількості опадів червня в роки досліджень (114,9 мм) для пшениці озимої становить 30,5 ц/га; для жита озимого 27,1 ц/га.

вання та моделювання впливу кліматичних факторів на урожайність та якість зерна сої в умовах центрального Лісостепу України : автореф. дис. на здобуття наук. ступеня канд. с.-г. наук : спец. 03.00.16 «Екологія» / В. М. Калініченко. - Житомир, 2005. -20 c.

5. Пасов В. М. Изменчивость урожаев и оценка ожидаемой продуктивности зерновых культур / В. М. Пасов. - Л. : Гидрометеоиздат. - 1986. $150 \mathrm{c}$.

6. Полевой $А$. Н. Прикладное моделирование и прогнозирование продуктивности посевов / А. Н. Полевой. - Л. : Гидрометеоиздат, 1988. $320 \mathrm{c}$. 
7. Попитченко Л. М. Погодно-кліматичні умови вегетації озимої пшениці в Луганській області / Л. М. Попитченко // Збірник наукових праць Луганського національного аграрного університету : [серія «Сільськогосподарські науки»]. - Луганськ: «Елтон-2», 2009. - № 100. - С. 121-124.

8. Соколов И. Д. Связь температуры атмосферного воздуха с урожайностью озимой пшеницы на юго-востоке Украины / И. Д. Соколов, Г. А. Стародворов, О. А. Мостовой // Збірник наукових праць Луганського національного аграрного університету. - 2006. - № 57 (80). C. 104-107.
9. Соколова Т. И. Вековая циклическая изменчивость климатических и агроклиматических факторов на юго-востоке Украины / Т. И. Соколова, Е. Д. Долгих, П. В. Шелихов [и др.] // Збірник наукових праць Луганського національного аграрного університету. - 2007. - № 75 (98). C. 146-153.

10. Тараріко Ю. О. Вплив агротехнічних і агрометеорологічних факторів на продуктивність агроекосистем / Ю. О. Тараріко, А. В. Чернокозинський, Р. В. Сайдак [та ін.] // Вісник аграрної науки. - 2008. - № 5. - С. 64-67. 